\title{
PENINGKATAN PENGETAHUAN TENTANG PENCEGAHAN PENYALAHGUNAAN OBAT PADA PELAJAR
}

\author{
Endra Pujiastuti ${ }^{1}$, Dian Arsanti Palupi ${ }^{2}$ \\ 1,2Program Studi D3 Farmasi STIKES Cendekia Utama Kudus \\ endra.pujiastuti@gmail.com; arsanti palupi@yahoo.com
}

\begin{abstract}
ABSTRAK
Kebijakan obat nasional mengatakan bahwa obat merupakan sediaan atau perpaduan bahan- bahan yang siap digunakan untuk mempengaruhi atau menyelidiki sistem fisiologi atau keadaan patologi dalam rangka penetapan diagnosa, pencegahan, penyembuhan, pemulihan, dan peningkatan kesehatan. Dalam menggunakan obat perlu diketahui efek obat tersebut, penyakit yang diderita, dosis, waktu pemberian dan tujuan obat itu digunakan. Berdasarkan laporan World Drug Report 2012 menyatakan bahwa pada tahun 2010 terdapat sekitar 230 juta orang atau sekitar 5\% penduduk dunia usia 15-64 tahun yang menyalahgunakan obat setidaknya satu kali dalam 12 bulan. Hal ini terus menambah beban global penyakit dan setidaknya sekitar 1 dari setiap 100 kematian di antara orang dewasa disebabkan dengan penyalahgunaan obat.Kegiatan pengabdian masyarakat ini bertujuan secara umum untuk meningkatkan pengetahuan pelajar tentang Penyalahgunaan Obat Dan Pencegahannnya.
\end{abstract}

Kata Kunci : Farmasi, Obat, Penyalahgunaan

\begin{abstract}
National drug policy says that drugs are preparations or mixtures of materials that are ready to be used to influence or investigate physiological systems or pathological conditions in the context of diagnosing, preventing, healing, recovering, and improving health. In using the drug, it is necessary to know the effect of the drug, the disease suffered, the dose, the time of administration and the purpose of the drug used. According to the 2012 World Drug Report, it was stated that in 2010 there were around 230 million people, or about 5\% of the world's population aged 15-64 years who misuse drugs at least once in 12 months. This continues to add to the global burden of the disease and at least about 1 in every 100 deaths among adults is caused by drug abuse. The purpose of this community service is to increase students' knowledge about drug abuse and prevention.
\end{abstract}

Keywords: Pharmacy, medicine, abuse 


\section{PENDAHULUAN}

Kebijakan obat nasional mengatakan bahwa obat merupakan sediaan atau perpaduan bahan- bahan yang siap digunakan untuk mempengaruhi atau menyelidiki sistem fisiologi atau keadaan patologi dalam rangka penetapan diagnosa, pencegahan, penyembuhan, pemulihan, dan peningkatan kesehatan. Dalam menggunakan obat perlu diketahui efek obat tersebut, penyakit yang diderita, dosis, waktu pemberian dan tujuan obat itu digunakan.

Obat keras, yaitu obat berkhasiat keras yang untuk mendapatkannya harus dengan resep dokter, memakai tanda lingkaran merah bergaris tepi hitam dengan tulisan huruf $\mathrm{K}$ di dalamnya. Obat-obatan yang termasuk dalam golongan ini berkhasiat keras dan bila dipakai sembarangan bisa berbahaya bahkan meracuni tubuh, memperparah penyakit, memicu munculnya penyakit lain sebagai efek negatifnya, hingga menyebabkan kerusakan organ-organ tubuh, bahkan dapat menyebabkan kematian.

Berdasarkan laporan World Drug Report 2012 menyatakan bahwa pada tahun 2010 terdapat sekitar 230 juta orang atau sekitar 5\% penduduk dunia usia 15-64 tahun yang menyalahgunakan obat setidaknya satu kali dalam 12 bulan. Hal ini terus menambah beban global penyakit dan setidaknya sekitar 1 dari setiap 100 kematian di antara orang dewasa disebabkan dengan penyalahgunaan obat.

Obat keras, yaitu obat berkhasiat keras yang untuk mendapatkannya harus dengan resep dokter, memakai tanda lingkaran merah bergaris tepi hitam dengan tulisan huruf $\mathrm{K}$ di dalamnya. Obat-obatan yang termasuk dalam golongan ini berkhasiat keras dan bila dipakai sembarangan bisa berbahaya bahkan meracuni tubuh, memperparah penyakit, memicu munculnya penyakit lain sebagai efek negatifnya, hingga menyebabkan kerusakan organ-organ tubuh, bahkan dapat menyebabkan kematian.

Obat bebas dengan logo bulat hijau merupakan obat yang secara luas dapat digunakan untuk pengobatan sendiri (swamedikasi) oleh remaja (pelajar) dan meningkat sejalan pertambahan usia. Tetapi 
beberapa penilitian menyebutkan bahwa remaja (pelajar) dan dewasa tidak menggunakan pengobatan sendiri (swamedikasi) secara benar. Adanya iklan yang memberikan informasi akan mempengaruhi keputusan pemilihan obat untuk penggunaan obat bebas.

Menurut Kementerian Kesehatan (2011) Pengobatan untuk dirisendiri (swamedikasi) sering dilakukan oleh masyarakat baik pelajar maupun orang dewasa. Dalam swamedikasi diperlukan persyaratan obat yang rasional.

Penggunaan Obat Rasional merupakan pengobatan sesuai dengan kebutuhan klinisnya, dalam dosis yang sesuai dengan kebutuhan, dalam periode waktu yang sesuai dan dengan biaya yang terjangkau oleh dirinya dan kebanyakan masyarakat.

Prevalensi pengobatan sendiri tanpa pengawasan orang dewasa mengalami peningkatan sebesar 30 persen pada usia dua belas tahun dan 70 persen pada usia delapan belas tahun namun beberapa penelitian menemukan bahwa remaja dan dewasa tidak melakukan pengobatan sendiri secara benar dan efektif [1]. Salah satu hal yang berpengaruh terhadap pemilihan obat dalam pengobatan sendiri yaitu informasi yang diperoleh dari iklan obat. Informasi obat yang sekarang bersifat komersil dan tersebar dalam bentuk informasi yang beragam. Informasi mudah diperoleh melalui berbagai media dan seringkali bias. Segi positif selalu lebih ditonjolkan sedangkan sisi negatifnya sering dilupakan bahkan sengaja tidak ditayangkan dalam iklan obat [2].

Apoteker dalam salah satu tugasnya yaitu memberikan informasi penggunaan obat pada masyarakat. Oleh karenanya di perlukan suatu cara peningkatan pengetahuan terhadap penggunaan obat yang rasional

Tujuan dari pengabdian masyarakat ini adalah Memberikan wawasan tentang Obat Dan Mensoaialisasikan pentingnya mengetahui penggunaan dan dampak penyalahgunaan obat pada pelajar. 


\section{METODE PELAKSANAAN}

Khalayak sasaran adalah siswa MA NU Ibtidaiah Kudus dan MTs NU Miftahul Falah, kegiatan dilaksanakan di kelas. Pelaksanaan pengabdian masyarakat dilaksanakan tanggal 30 April 2018.

Kegiatan pengabdian ini menggunakan metode ceramah, Tanya jawab dan demonstrasi. Dalam demonstrasi diperagakan cara pengenalan golongan obat dari penandaan yang tertera pada kemasan. Kemudian dibuka kesempatan untuk Tanya jawab.

Evaluasi dilakukan pada tahap akhir kegiatan. Evaluasi diberikan dengan mengobservasi kemampuan siswa dalam menjawab pertanyaan yang diajukan pengabdi tentang bagaimana pengg Indikator tercapainya tujuan pengabdian adalah peningkatan pengetahuan pelajar tentang penggunaan, dampak serta pencegahan penyalah gunaan obat. bahwa siswa memahami pentingnya tujuan dan manfaat edukasi, sehingga dapat meningkatkan pengetahuan siswa terhadap penggunaan, dampak serta pencegahan penyalah gunaan obat.

\section{HASIL DAN PEMBAHASAN}

Penyuluhan dimulai dengan penjelasan tentang definisi obat, penggolongan obat, definisi Apoteker, penggunaan obat yang rasional dan dampak penyalahgunaan obat. Para siswa ditekankan mengenai pentingnya mengetahui dampak dan pencegahan penyalahgunaan obat. Melalui penjelasan ini diharapkan siswa MA NU Intidaul Falah dan MTs NU Miftahul Falah Kudus mengetahui dan memahami semua materi. Setelah penjelasan kemudian dilanjutkan dengan cara pengenalan golongan obat. Siswa juga diberi penjelasan bahwa Penggunaan obat yang tidak rasional dapat berakibat buruk pada kesehatan

Kegiatan penyuluhan diakhiri dengan sesi tanya jawab dimana respon siswa MA NU Ibtidaul Falah dan MTs NU Miftahul Falah Kudus sangat baik terlihat bersemangat saat menjawab pertanyaan yang disampaikan pengabdi. Berbagai pertanyaan tersebut merefleksikan 
keingintahuan siswa mengenai penggunaan dan penyalahgunaan obat. Diharapkan melalui kegiatan ini tujuan akhir yang ingin dicapai dapat terwujud serta siswa menjadi lebih perhatian dalam menjaga kesehatan dengan bijak menggunakan obat.

Kegiatan pengabdian masyarakat di MA NU Ibtidaul Falah dan MTs NU Miftahul Falah Kudus mendapatkan respon baik dari para siswa peserta penyuluhan. Secara umum hasil pengabdian meliputi beberapa aspek pencapaian yaitu Ketercapaian tujuan kegiatan pengabdian masyarakat tentang peningkatan pengetahuan siswa tentang jenis obat dan penggunaan obat yang rasional. kemampuan siswa dalam menjawab pertanyaan dan materi yang direncanakan dapat tersampaikan dan didukung dengan hasil pembuktian evidence based yang dilakukan pengabdi secara langsung. Ketercapaian target materi pada kegiatan pengabdian masyarakat ini cukup baik, karena materi telah dapat disampaikan secara keseluruhan.Kemampuan peserta dalam menguasai materi dengan melihat Kemampuan peserta dilihat dari kemampuan siswa sudah mampu menjelaskan kembali tentang materi tersebut.

Beberapa faktor pendukung maupun penghambat dalam kegiatan pengabdian pada masyarakat ini adalah Faktor pendukung yakni adanya respon positif dari siswa MA NU Ibtidaul Falah dan MTs NU Miftahul Falah Kudus dalam kegiatan dan tersedianya sarana dan prasarana penunjang yang memadai. Faktor penghambat yakni Dalam pelaksanaan kegiatan tidak dapat dilakukan pada keseluruhan siswa, hal ini dikarenakan kurangnya waktu dan padatnya kegiatan di MA NU Ibtidaul Falah dan MTs NU Miftahul Falah Kudus.

\section{SIMPULAN DAN SARAN SIMPULAN}

Pelaksanaan penyuluhan sebagai salah satu program pengabdian masyarakat yang berjudul "Peningkatan Pengetahuan Pelajar Terhadap Pencegahan Penyalahgunaan Obat " telah terlaksana dengan baik dan 
mendapatkan respon yang baik dari siswa/ peserta serta tercapainya target yang diharapkan.

\section{SARAN}

Berdasarkan evaluasi yang telah dilakukan maka saran yang diajukan antara lain :

- Bagi tenaga Dosen

Perlu adanya kegiatan untuk memperluas wawasan terkait pengembangan pengetahuan tenaga farmasi khususnya pada penyalahgunaan obat

- Bagi Siswa MA NU Ibtidaul Falah dan MTs NU Miftahul Falah Kudus Perlu adanya kegiatan sosialisasi di bidang kesehatan yang sangat bermanfaat dalam meningkatkan kesehatan masyarakat.

\section{UCAPAN TERIMAKASIH}

1. Program Pengabdian Masyarakat ini dibiayai oleh STIKES Cendekia Utama Kudus dengan Surat Keputusan Kontrak Pengabdian Masyarakat Nomor : 014/SK-PI/LPPM-STIKES CU/V/2018

2. Kepala Sekolah MA NU Ibtidaul Falah dan MTs NU Miftahul Falah Kudus

\section{DAFTAR PUSTAKA}

1. Thompson.W.M. and Poulton.R. 2002, Medication taken by 26 years old, Internal Medicine Journal, 32:305-310.

2. Gray, N.J., Cantrill, J. A., \& Noyce, P. R. (2002). 'Health repertories': An understanding of lay management of minor ailments. Patient Education and Counseling, 47, 237-244. 